\title{
Research on embryos in Turkey with ethical and legal aspects
}

\author{
Etik ve yasal açıdan Türkiye'de embryo üzerinde araştırmalar
}

\author{
Emine Elif Vatanoğlu-Lutz \\ Department of Medical History and Ethics, Faculty of Medicine, Yeditepe University, Istanbul, Turkey
}

\section{Abstract}

Technically, the term embryo refers to the products of conception after implantation into the wall of the womb, usually nearly two weeks after fertilization, up until the eighth week. Embryos contain stem cells which, according to scientists, could be used to cure a wide range of conditions. Stem cells can be coaxed into growing cells of any other type, which makes them potentially very useful indeed. However, removing stem cells from an embryo will kill the embryo, which some people object to. From the mid 1970s, IVF was being developed and research was carried out on the spare embryos produced. This research helped to improve IVF techniques, as well as to better understand the earliest stages of human development. Research also shed light on a variety of inheritable disorders. In Turkish Law, assisted reproduction treatment (ART) services are regulated with the Regulation of Assisted Reproductive Treatment Centers Act (RAPTCA) The Regulation was issued in 1987, but it has been amended several times since. Also, article 90 of the Turkish Penal Code covers some aspects of research on embryos. At the same time, the Biomedicine Convention (Oviedo Convention), signed by Turkey and which entered into force in 2003, has binding regulations about this issue. Different legal regulations and some ethical guidelines are in conflict with each other, creating much confusion for the researchers. In this paper these conflicts are discussed, giving some practical proposals.

(J Turkish-German Gynecol Assoc 2012; 13: 191-5)

Key words: Embryo, research, genetics, law, ethics

Received: 07 August, 2012

Accepted: 15 August, 2012

\section{Özel}

Embryo terimi fertilizasyondan itibaren sekizinci haftaya kadar olan gebelik materyalini tarif etmek için kullanılır. Embryo, çok geniş ve farklı yelpazedeki patolojileri tedavi etmek için kullanılabilecek kök hücrelere sahiptir. Kök hücreler köken aldıklan hücre tipinden farklı yapıdaki dokuları oluşturmak üzere yönlendirilebilirler ki bu özellikleri nedeniyle kullanışlı olma potansiyelleri artmaktadır. Ancak kök hücrelerin embryodan uzaklaştırılması embryonun ölümüne neden olacaktır ki bu durum birçok kişinin karşı çıktığı noktadır. 1970'lerin ortalarından itibaren uygulanan in vitro fertilizasyon (IVF) işlemleri sırasında elde edilen fazla embryoların araştırma amacıyla kullanılması gündemdedir. $\mathrm{Bu}$ araştırmalar hem IVF tekniklerinin gelişmesine hem de insan gelişiminin ilk evrelerinin daha iyi anlaşılmasına yardımcı olmuştur. Bu araştırmalar aynı zamanda birçok kalıtımsal hastalığın aydınlatılmasına da yardımcı olmuştur. Türkiye'de üremeye yardımcı tedaviler Üremeye Yardımcı Tedavi Merkezleri Yönetmeliği ile düzenlenmektedir. Bu yönetmelik 1987 yılında yürürlüğe girmiş olup ardından bir dizi değişiklikler geçirmiştir. Ayrıca Türk Ceza Kanunu'nun 90. maddesi embryo üzerinde yapilacak araştırmalarla ilgili bazı hususları kapsamaktadır. Ayrıca Türkiye'nin 2003 yılında imzaladığı Avrupa Biyotıp Sözleşme (Oviedo Konvensiyonu) konuyla ilgili bağlayıcı hükümleri vardır. Türkiye'deki yasal düzenlemeler araştırmacılar açısından karışıkığa yol açacak nitelikte ve netlikten yoksun gözükmektedir, konuya özel olarak belirlenmiş spesifik bir yasal düzenlemenin bulunmayışı büyük eksiklik yaratmaktadır. Bu makalede konunun yasal ve etik yönleri bazı öneriler doğrultusunda tartışılmıştır. (J Turkish-German Gynecol Assoc 2012; 13: 191-5)

Anahtar kelimeler: Embryo, araştırma, genetik, hukuk, etik

Geliş Tarihi: 07 Ağustos 2012

Kabul Tarihi: 15 Ağustos 2012

\section{Introduction}

Ethical and legal debates on embryo research have again become an important item in our agenda when European Court of Human Rights (ECHR) General Assembly passed judgment on the application of a British lady in 2007. This late legal debate requires long attention from those who are engaged in medicine and legal sciences. We can make a short summary of the event as follows:

A British woman has to undergo major surgery because of her health problems. She was engaged at that time. The woman's ovaries are to be taken with this operation, and there would be no chance of her having a child after the operation. Therefore, sperm and eggs are taken from the couple prior to the surgery, eggs are fertilized artificially and embryos are stored frozen. After the medical intervention, the engagement is broken due to a dispute between the couple. Her ex-fiancee stated that he did not want to have a child with the woman and demanded the termination of the frozen embryos.

Since there is no chance for her to have a child because her ovaries are removed and trusting only to the frozen embryos, 
the woman applies to the sperm bank to get pregnant with frozen embryos. With her ex-fiancée's objection, the issue becomes a judiciary issue. Consuming domestic remedies and stated unjust in every judicial body in the UK, she carries the issue to the EHCR. EHCR Court No. 5 judges that the man is equally entitled to the embryos and rejects her request. As la ast resort she applies to the Grand Chamber of the EHCR. In 2009, the General Assembly of the Grand Chamber decides that both parties have unique rights of ownership on sperm/ovaries and the woman can not be impregnated via In vitro fertilization without the consent of her ex-fiancee. While her ex-fiancee is waiting for the legal process of termination of the embryos in a short time, he is shocked by the news that she was in fact pregnant, taking the embryo from the bank by imitating his signature and via fake documentation. Whether or not the statutory period of time for embryo termination is passed, since a medical necessity, or a legal requirement, and most importantly the consent of the woman is not present, abortion of the embryo/fetus was not an option from that point on, and despite his objections, the ex-fiancee is to become a father (1).

Both this case and some other cases which have been brought in front of the ECHR in the last three years have caused a big ethical, medical and legal debate around European Council Convention of Biomedicine provisions.

When we look at the legal approach regarding in vitro fertilization in Turkey, we see that the in-vitro fertilization method is accepted as a method of treatment and not a research method, and social insurance institutions are able to cover the treatment expenses (Council of State Department 5, 1998/3529 Acts in 20.09.2001 and 2001/3138 Acts). Before these laws, Turkish laws had judged with artificial reasons that in-vitro fertilization was not a method of treatment and its medical expenses could not be paid for by the state as health care, even though the regulation concerning this issue had clearly stated otherwise. Likewise, the Religious Affairs Department has defined IVF as "a procedure which hurts feelings of humanity" and "adultery" in its decision of the High Council of Religious Affairs in 2002 (1).

\section{Contributions From Turkey}

However; to give way to scientific research and to prevent abuses, various studies within the framework of human rights, human dignity and freedom of science and art are currently being conducted in European countries. These studies aim to make the human dignity concept tangible and functional, pursue the freedom of science and try to prevent abuse of medical research projects, particularly subjects like embryo research, in-vitro fertilization, stem cells and drug trials. For example; $\mathrm{ZiF}$ in Bielefeld, Germany (Cross-Cultural Research Center) has launched the "Human Design, and Human Dignity" project 2 years earlier in this context. The project employs dozens of expert scientists working on different branches such as law, ethics, religion and social studies, who work seamlessly in this regard to achieve tangible outcomes. One of the major sub-topics of this project, which began on 2009 and is to be published as a book in 2010, is embryonic research (2).

With contributions from Prof. Dr. Yener Ünver and Dr. Altan Heper from Turkey, the project aims to eliminate the com- mon dilemmas between law and science, to achieve common, secure, open and fundamental human design criteria suitable for the $21^{\text {st }}$ century and to create theories regarding basic human rights. One of the most controversial issues in this subject is whether or not the embryo should benefit from the human dignity concept and rights, how to maintain its legal protection regarding the human dignity concept, while technically not being human itself (2).

\section{Discussion of Current Legal Legislations About the Issue}

\section{The Biomedicine Convention (Oviedo Convention)}

The Biomedicine Convention which is promulgated by the Council of Europe and accepted by Turkey in 2003, includes arrangements on this issue in its articles numbered $2,11,13,15$, 16, 17 and in particular 18 and 23. Article 18/1 of this convention regulates the necessity of protection for the embryo on the basis of national regulation allowing IVF research. Article 18/2 of the convention, on the other hand, prohibits the creation of human embryos only for research purposes. This issue should be considered along with the ban on cloning stated in the European Declaration of Fundamental Rights. Several European countries such as Germany, have not yet acknowledged this agreement with a concern of prohibitation of cloning for stem cell research and planning to do so after an additional protocol is maintained or the main agreement text is modified regarding this issue. These countries have the widely held opinion that the Convention, in its current form, seriously limits the scientific research projects contrary to the dominant purpose of these studies. Additional protocol to the Convention prohibits human cloning and states (in the introduction section) that cloning is a misuse of medicine technique and an abuse of human dignity (3).

Turkey's only objection to the Convention was in terms of Organ-Tissue Transplantation Act (OTTA). This incorrect drawback has not yet been removed since 2003 and OTTA is yet to be changed to compensate for the contradiction between the Convention. Turkey's objection to the Convention is based on OTTA article no. 5 which bans inter-family organ and tissue transplantation on minors (younger than 18 years old) according to Turkish legislation (4).

\section{Turkish Penal Code}

Turkish Constitution article 90/5 dictates that "No appeal to the Constitutional Court can be made with regard to international agreements, on the ground that they are unconstitutional." This Convention is subject to that article.

Turkish Constitution article 17, entitled "Personal Inviolability, Material and Spiritual Entity of the individual" dictates in 2. that "The physical integrity of the individual shall not be violated except under medical necessity and in cases prescribed by law; he shall not be subject to scientific or medical experiments without his consent." According to article 27, entitled "Freedom of Science and Arts", paragraphs 1 and 2; "Everyone has the right to study and teach freely, explain, and disseminate science and arts and to carry out research in these fields." and "The right to disseminate shall not be exercised for the purpose of changing the provisions of Articles 1, 2 and 3 of this 
Constitution." In other words, the right to exercise material sciences shall not be interpreted as the right to ignore the individual's rights to live, protection and development of tangible and intangible assets (4).

Article 90 of Turkish Penal Code states that any person who carries out a scientific experiment on a human being shall be sentenced to a penalty of imprisonment for a term of one to three years. However, these regulations do not cover research studies on embryos. Currently, there is no direct legal regulation that prevents embryo research. There is only the ODNK law to apply to embryo plantation situations, since an embryo consists of tissues and tissue transplantation is-incorrectly-regulated in the ODNK law. So in case of embryo transplantation, those who participated shall be subject to relevant provisions in the Turkish Penal Code article 15 which regulates criminal penalties regarding tissue transplantation (5).

\section{Regulation of Assisted Reproductive Treatment Centers Act (RAPTCA)}

There is no unique regulation or act regarding In Vitro Fertilization (IVF) in Turkey. This area is regulated via the Regulation of Assisted Reproductive Treatment Centers Act.

A short time ago (2009) a new Regulation on Clinical Research made by the Ministry of Health was put into effect. While article 13 of the Turkish Constitution clearly states that "regulations regarding fundamental rights shall only be achieved through laws and no other legal norms", with above statute the Ministry of Health effectively limited the freedom of research and science. For example the Turkish Penal Code article 90 regulates that, in certain conditions, experimentation on humans can be done. However, the above guideline completely prohibits any research on children, pregnant women or people who are not able to give written consent, even though this is not written in the law (Article 5). The exception to this rule is that: "if it provides a direct benefit in terms of people treated and if there is written permission from the Ministry of Health, it is possible to conduct tests and trials". This arrangement cannot be done via guidelines and should be arranged via law. This is a requirement of both relevant articles of Biomedicine Convention and articles 13 and 90/5 of the Turkish Constitution.

According to this regulation, including revision text dated March 6, 2010; uncontrolled ovarian hyperstimulation by physicians or other individuals, opening special clinics for in-vitro fertilization (IVF) and micro-injection (ICSI) practices or assigning a part/area of current clinics for these purposes are prohibited. These types of activities shall be immediately stopped by the governor's office and the republican prosecutor's office shall be informed of the involved parties concerning judicial process. This provision does not have any importance in terms of penal law; and these kindsof medical interventions, despite the provisions of this regulation, shall not constitute a crime (6).

According to article 18/12 of RAPTCA; in the case of obtaining more embryos from the candidates, embryos are stored frozen with the consent of both spouses. Should the storage period exceed one year, spouses should re-apply every year stating their continuous demand for preservation of the embryo, with written and signed declarations. In cases of mutual request from the spouses, death of one of the spouses, divorce or end of the fixed period of preservation, the embryos shall be destroyed/terminated after being recorded by a commission established by the directorate. Should there be an electronic record system set forth by the Ministry of Health, information regarding the embryos shall be recorded in that system.

According to article 18, paragraph 13 of RAPTCA, the samples aforementioned in the 11 . and 12. paragraphs of the same article shall be stored no more than five years. A storage period of more than five years is subject to the permission of the Ministry of Health. Counting and evaluation of the stored samples shall be carried out by means of the commission which is to be established within the relative directorate. Should samples which have not been recorded in time are detected, administrative sanction in the form of supervision shall be carried out. Since these actions do not constitute a crime, they do not have a criminal law penalty and are subject to administrative sanctions (7).

Legal arrangements should be made in order to prevent illegal reproductive tourism from Turkey to Greece, Belgium, Rhodes Island and Northern Cyprus. Illegal ova/embryo transplantation should be recognized as a crime regulated by law by these arrangements. The lack of these regulations, along with many dangers and risks, causes these operations to be carried out in above-mentioned countries, crimes mentioned in Turkish Penal Law articles 91-93 to be committed, organ-trafficking and young girls to sell their ovaries for money. When these actions, committed in foreign countries, constitute a criminal offence, their prosecution in Turkey is not possible according to the Turkish Penal Code article 11. These actions should be regulated so that they constitute a criminal offence even when they are committed in a foreign country, the need for realization of the action as a crime by the relevant foreign country should not be a necessity and it should be ensured that these crimes can be prosecuted also in Turkey (8).

If heterologous artificial fertilization is not legally regulated and sperm banks, and more importantly sperm and ova donations are not subject to coding and categorizing, both medically and legally unfavorable situations are sure to arise, including unintended inter-sibling marriages in future years. Neither medicine nor law can be said to aim at these consequences $(9,10)$.

\section{Discussion}

Today, often one or two fetal/fetuses are selected in multiple pregnancies and the remainder are removed by curettage after the statutory 10 week period, although there is no medical necessity. The parent's consent/request only, does not make this process legal for both parents and the medical staff, the process still remains illegal and if proven, those involved are still subject to a legal penalty regarding the abortion law stated in the Turkish Penal Code article 99.

On the other hand, application for embryo reduction is carried out mostly via the abdominal route and on weeks 11-12 of the pregnancy. Since in this case this operation cannot be regulated within the framework of "abortion crime" (Turkish Penal Code Articles 99-100), this subject should be re-regulated 
in the Turkish Penal Law and Law on Population Planning. Also the future planned Embryo Protection Act should include provisions regarding this issue.

A similar medical practice is the determination of the sex of the fetus via intervention by medical personnel. These practices, the use of which the Biomedicine Convention has permittedonly-on genetic diseases and prohibits their usage on all other cases, are still not in current legislation in Turkey, so these actions go unpunished since they are not recognized as types of crimes $(3,8)$.

Although the above-mentioned Regulation of 2009 prohibits pharmaceutical research on pregnant, nursing and puerperant women; because it is not possible to recognize a practice as a criminal act by Regulations (not laws) and also because bans on scientific research (which is a human right) are unimportant when it comes to Turkish Constitution article 13, these regulations are basically meaningless (11).

Turkish legislation in this area lacks important and overdue regulations to be filled. These legal arrangements that should be carried out are essentially a part of international law and approved conventions. In this context, a special law for the protection of the embryo should be regulated, the Stem Cell Act should be legalised, an urgent law regulating Protection of Personal Data, Data (DNA) Bank, Biobanking Act should be passed and a law concerning Biobanks should be constituted (7).

Over-production of embryos should be recognized as a crime and should be punishable. All the same, unlawful destruction of the embryos, embryonic research against the law (experiments and trials) must be punishable and embryo storage, transportation and disposal should be controlled by strict regulations. Just like blood transfusions, tissue transplantation must be arranged separately from organ and tissue transplantation laws, regulated by its own law (12).

Naturally produced embryos are under the protection of the Turkish Penal Code articles 99 and 100. The regulations of aforementioned articles in TPC apply to embryos after their placement into the uterus, but there are no provisions about pre-placement. Legal regulations on this subject are needed. Abuse of in-vitro fertilization methods and human embryo should be a crime; embryo/fetal gender determination interventions should be illegal on the norms of penal law unless there is a medical necessity; the law should clearly state the permitted and forbidden forms of using reproductive cells for the purpose of conception after death; a sperm bank should be established and regulations which block scientific research should not be given a place in the law. A discrimination ban law should be established regarding disabled fetal-infants. Again, the "surrogate mother/womb renting" issue should be clearly organized by law concerning the impact on the Turkish Civil Code and penal law fields. Creation of human-animal embryo hybrids and medical interventions using a different genetic mix of cells to create embryos should be recognized as a crime and should be prohibited.

Again, if spouses demand their frozen sperm/ova from the institution in order to use it for artificial insemination in a different public or private institution, they are often denied the request or given the sperm/ova without due diligence. Even if these stored sperm or fertilized/unfertilized eggs are given to spouses on demand; this extra action is recognized both as physical violence and sexual assault in legal scope because it is illegal to obtain and/or freeze the ova without the consent of spouses. Also storage of the ova is in violation of the regulation article $17 / 5$. These actions require administrative sanction regulated in the aforementioned regulation article 18 paragraph 1 . However, there is no regulation regarding the penal code.

RAPTCA article number 17/1 dictates that "Possession, usage, transfer and sale of embryos, usage and application of embryos obtained from a candidate on different candidates or application of embryos obtained from a non-candidate on a candidate are strictly prohibited". The Council of Europe Convention on Biomedicine article number 21 dictates that "The human body and its parts shall not, as such, give rise to financial gain." Article 22 of the Convention regulates that "When, in the course of an intervention, any part of a human body is removed, it may be stored and used for a purpose other than that for which it was removed, only if this is done in conformity with appropriate information and consent procedures".

However there is no penal code regulation or legal arrangement for medical inventions done in hospital-clinics not due to the Ministry of Health and no administrative penalty applies (13).

According to the article text, "No more than three embryos shall be transferred in medical centers which employ assisted reproductive techniques. In cases where the transfer of more than three embryos are required, such as the age factor, quality of embryos and similar medical necessities, the doctor shall document the medical rationale." In contrast, there is comparative law protection of the embryo, which will be used, and in particular the prohibition of unlawful destruction (required) number of banning the production of more embryos, and in particular there is a regulation that punishes the criminal law norms. On the contrary, RAPTCA clearly provides an opportunity for the production of more (than required) embryos and does not regulate their necessity of termination after and this is not acceptable by law.

RAPTCA article number $17 / 5$ states that, with the consent of both spouses, freezing and storing of the embryos are possible and these embryos can be used by the same candidate within the period specified by the registration center (this period could not exceed 5 years). However, regulation article $17 / 5$ lacks some information like embryo conditions and who to be responsible for the embryos when the medical center is shut down or relocated to another city, whether embryos are to be transferred to another facility or to be terminated, the legal responsibility for transferee medical clinics and centers, how the procedure is to be carried out when the patient requests his/her embryos for transfer to another facility. These should be regulated along with embryo storage provisions (14).

The Turkish Penal Code article 99 paragraph 6 dictates that "Where a woman is pregnant due to an offence that she was a victim of, no penalty shall be imposed upon any person who terminates such pregnancy, where the term of pregnancy is not more than twenty weeks and there is consent from the woman. "However, both the termination of the embryos and producing more than the required amount should be regulated 
and recognized as a criminal act and the Turkish Penal Code article 99 paragraph 6 should be reorganized in order to correct the mistakes and fill in the lacking provisions. Therefore, the Turkish Penal Code article 99 paragraph 6, which dictates: "Where a woman is pregnant due to an offence of which she was a victim, no penalty shall be imposed upon any person who terminates such pregnancy, where the term of pregnancy is not more than twenty weeks and there is consent from the woman." should be revised (4).

\section{Conclusion}

The concept of Human dignity should be widened to allow understanding and protection of the life of the fetus. Since the aforementioned article requires only the consent of the mother and does not require any medical necessity and employs no control mechanism, it allows abuse from the institution and provides opportunity for the violation of human dignity. Worse yet, there is no criminal or penal responsibility if medical personnel, health care providers, including the mother, abuse this system. The fetal body/placenta etc. from abortion is subject to be used for the pharmaceutical industry and this violates the norms which prohibit using human body parts for financial gain. Current lack of legal regulations also give way to frauds carried out against the law by hiding behind the Turkish Penal Code articles 91 and 93, which regulate organ and tissue transplantation laws and this allows people who discriminate betqween male-female children to terminate undesirable gender fetuses, for example female fetuses can be put to death when spouses do not want a girl baby (4).

The revision of article 99 of the Turkish Penal Code should include the following: Pregnancy duration must not be less than 20 weeks. The fact that the cause of pregnancy was really a criminal act must be determined "not only" by the mother's statement and by other legal mechanisms. Whether or not there is a reason preventing anti-abortion measures must be checked during the normal abortion period (not exceeding 10 weeks) and these and following interventions on the fetus must be regulated by law (4).

Finally, the Turkish Penal Code article 92, which regulates organ trafficking states "A penalty may be reduced or not imposed at all, after considering the social and economic conditions of the person selling his own organs or tissue." This statement is against the law and is often being abused. How satisfactory is an arrangement that penalizes a doctor, coordinator or the receiver of the organ (who possibly saves his/her own life by doing so) and not giving a normal penalty to countrymen who sell their organs for money, or reducing their penalty?

The goal must be the protection of human dignity and the paving of the way for scientific research at the same time. Unrestricted, excessive prohibitions are part of the problem not the solution.
Surely there is an important issue which should be taken into consideration here. The first article of the Turkish Constitution regulates that human dignity is inviolable, but it is not enough for human dignity to be protected. Currently, the human dignity concept is vague, there is no clear definition of human dignity which is satisfactory for everyone.

\section{Conflict of interest}

No conflict of interest was declared by the authors.

\section{References}

1. Ünver Y. 'Türkiye'de Ceza Hukuku Açısından Sun'i Döllenme' (In Vitro Fertilization According to Criminal Law in Turkey), Book of Ethical and Medical Problems Symposium, İstanbul, October 2008, p. 21.

2. Hugel B. "Kunstliche Befruchtung-Eine Ausweg bei Unfruchtugbarkeit?", Schriftenreihe der Aktion Leben, Nr.6, 3.Auslage, Absteinach 2002, p. 11.

3. Rosenau H. 'Avrupa Konseyi Biyo-Tıp Sözleşmesi'ne Göre Embriyon Araştırmaları ve Tedavi Amaçlı Kopyalama' (The Researches on Embryos According to European Council Biomedicine Convention and Cloning for Therapeutic Purposes), Archive of Public Law, İstanbul, November 2005, p. 137.

4. Ünver Y. 'Avrupa Biyo-Tıp Sözleşmesi'nin Türk Hukukuna Etkileri' (The Effects of European Biomedicine Convention on Turkish Law), Archive of Public Law, İstanbul, November 2005, p. 182.

5. Hakeri H. 'Tıp Hukukuna Giriş (Tıp Hukukunun Temel Kavramları)' (Introduction to Medical Law -Basic Concepts of Medical Law), Book of Roche Health Law Days, İstanbul, August 2007, p.3.

6. Vollmann J. 'In Vitro Fertilisation', İlaç ve Tıp Alanında Ceza Hukuku, Etik ve Tıbbi Sorunlar Sempozyumu Kitabı, İstanbul, Ekim 2008, p. 7.

7. Hot I. 'Attitudes Towards Research On Stored Tissue Samples' Proceedings of International Workshop on Advanced Clinical Research Ethics, İstanbul, December 2009, p. 197.

8. Cin O. 'Biyo-Tıp Sözleşmesi ve İnsan Üzerinde Deney' (The Biomedicine Convention and Research on Human Beings), Archive of Public Law, İstanbul, November 2005, p. 199.

9. Demirhan Erdemir A. 'Üretim Fonksiyonu İle İlgili Tıbbi Uygulamaların Tıbbi Etikte Yeri ve Bazı Orijinal Sonuçlar' (The Meaning of Medical Practices About Reproductive Functions in Medical Ethics and Some Original Results), Turkish Clinics Medical Ethics Journal Türkiye Klinikleri, No. 1, 1993, p. 28.

10. Arda B, Şahinoğlu P, Kayı S, Cangır A, 'Yardımcı Üreme Tekniklerinin (IVF'nin) Getireceği Tibbi Etik Sorunlar' (Some Medical Ethical Problems Caused by In Vitro Fertilization), Turkish Clinics Medical Ethics Journal, No. 1, 1993, p.54.

11. Özbek H. 'Regulation Regarding Clinical Trials', Proceedings of International Workshop on Advanced Clinical Research Ethics, İstanbul, December 2009, p. 90.

12. Lilie H. 'Suni Döllenme Alanında Yeni Problemler' (New Problems in the Field of Artificial Insemination), Archive of Public Law, İstanbul, November 2005, p. 113.

13. Ünver Y. 'Hekimin Cezai Sorumluluğu' (The Criminal Liability of Doctors), Book of Roche Health Law Days , İstanbul, August 2007, p.162.

14. Yenerer Çakmut Ö. 'Aydınlatma ve Rıza' (Giving Information and Consent), Book of Roche Health Law Days, İstanbul, August 2007, p.77. 